\title{
迂闊な 先入観
}

Absent-minded preoccupation

塩田亘*

Nobu SHIOTA*

数年前の事であるが，私は知らない中国人から一通の航空便を受取った。その十年ほど前に，私は中 国機械（中国語では「机械」）工程学会の招聘で訪中し，北京で開催された技術交流会（とはいっても 日本側の一方的な講演であったから，実態は彼等にとっての勉強会であったが）に出席し，二週間ほど 毎日午前中一杯, 中国の同業者を相手に講演した経験があるので，その時参加したメンバーの一人では ないかと思い，当時のメモを調べたが該当する名前は発見できなかった。

封を切りながら咄差に私の脳裏を掠めたのは, もしこの手紙の中身が中国語で書かれていたら, 如何 しょうかといら心配であった。中国人を相手に長時間講演した経験があるといっても，それは日本語に 堪能な中国人通訳を介しての事で，私自身の中国語の能力は，俄仕込及の極めて簡単な挨拶用の会話が でき，また路上や屋内に見られる中国特有の政治的，経済的，あるいは社会道徳的スローガン（今，日 本で流行している「四字熟語」で構成されていた）が理解できる程度で，文章を読解できる力は全く持 ち合わせて居なかったからである。

国際交流の書簡であるから国際語になっている英語での記述を期待しつつ封を切ったが，出てきた便 箋は手書きの漢字だけで埋め尽くされて拈り，私が一番気にしていた中国語による記述であった。

困惑のまま手を拱いて居るわけにもゆかず，見知らぬ字があっても意味が判れば，大まかな文意の把 握が出来るのではないかと思い，独学で読解して見よらと決心した。同じ漢字を使用する言語とはい え, 意味は必ずしも同じではなく, また前述した様に日本語には見られない文字も出て来るので, 中国 語の辞書が必要になり, 生れて初めて一冊（後述する様な経緯で最終的には二冊になったが）の辞書を 購入し，その引き方から勉強を開始した。

こうしてこの手紙の内容は，私がその二年ほど前に業界誌「素形材」に発表した論文についての質問 「らしい」ことが判明した。しかし彼の要望に忠実に応觉るには，「らしい」では済まされず，更に詳し く翻訳をする事にした。それには文法の知識が必要となるが，その学習には時間が要るので, 手っ取り 早い手段として熟語や句・用例の豊富な第二の辞書を探し求め, その中から類似の用例を見出し，それ と比較して大略正確な翻訳を得る事が出来た。

最終的に読解した結果では，この手紙の内容は以下の如きものであった。彼は私と同様にアルミニウ ム合金，特にピストン用合金の技術者で，私の論文の中国語抄録を作っていて，幾つかの疑問と翻訳の 対象が複写本であった為写真が不鮮明で, 鮮明な写真が欲しいといら要望が生じたので, それを記した ものであった。 
私はこの手紙を受取った当初より，「迂闊な先入観」の支配を受けていた。その「迂闊な先入観」と は，実際は「彼は日本語が理解できるから，日本語論文の中国語抄録を作っていた」のであるが，中国 語による手紙を見た瞬間に，「彼が中国語による手紙を書いたのは，彼は日本語が理解できないからで ある」，と思い込んでしまったのである。したがって，返信を如何しょらかといら困惑が生じ悩んだ末 に，少しは書き慣れている英語で返信する事を思いつき，「私の中国語は未熟です。貴下の中国語によ る書簡はどうにか読解しましたが，作文能力は全く無いので……と前置さして彼に返信を出した。

それから約一ヶ月経過して，彼から再び書簡を受取った。大方私の返信に対する礼状だろらとは想像 したが，もし更に質問や要望があったとしても，今度は二度目になるので短時間で中国語が翻訳でき， 迅速にレスポンスできると確信していた。

しかし，開封して出て来た便箋には，今度は中国語ではなく日本語で記述されていた。この瞬間私は 放心状態から吾に戻った様に，「そうだ，彼は日本語が判るのだった。」と，「迂闊な先入観」から解放 される事ができた。手紙の主旨は予想通り私の返信に対する礼状であったが，冒頭に「英語でご返事を 頂きましたが，実は私は英語よりも日本語の方が良く判るのです。最初に中国語で扮手紙を差し上げた のは，稚拙な日本語では迷惑を掛けるのではないか，と思ったからです。」を意味する文面が見られた。 それについての詳しい事情は記されて居らず，そしてその後彼との文通が途絶えているので，この前 置きの背景は紏明できないで居るが，私の推測する限りでは，その裏に「中国語では迷惑を掛けないだ ろら」といら彼の認識が窥われ，その認識は私と同様に以下に記述する如き「迁闊な先入観」によるも のではないか，と思っている。

すなわち，彼は，私が中国語を良く理解している，と独り決めしていたものと思われる。彼はどらし てその様な先入観に支配されたのであろらか。それは前述した技術交流会に彼は出席していなかった が，伝聞あるいは機関誌等の記事から大きな関心を持って居り，「素形材」誌上の論文著者が以前に訪 中し，長時間にわたる講演をした者と同一人物であると知り，その人だったら中国語が堪能に違いな い，と思い込んだものと思う。技術交流会に出席して居れば，私が中国語がわからない事を知った筈な のであるが。さらに彼は，自分が「相手の国の日本語」がわかるので，私も「相手の国の中国語」がわ かって当たり前との，先入観もあったかも知れない。

この種の「先入観」は，理路整然な思考の下では生じないものである。正に「迂闊」の産物以外の何 物でもない。人間としての生き方の中には，「称呼」や「指差」等の手段を用い，さながらュンピュー ターに拈ける二進法の運算の様に, 現状を充分確認してから次の行動に移らねばならない事象も少なく ない。その様な場合には「迂闊」や「ウッカリ・ミス」は，全く許されないものであるが，これを遵守 するには大きな精神上のストレスを伴ら。したがって四六時中この状態を保つ事は，精神医学上よくな いと同時に不可能でもある。

生活に「ゆとり」や「潤い」を持たせるためには, 許される範囲の「迂闊」や「ウッカリ・ミス」が あっても良いと思う。「迂闊な先入観」から発した結果でも実害の伴わないものは, 適当な緊張の弛緩 を誘い, ニーモア性にも富みリクリェーション効果も持っている。

以上の一件は, お互いに「迂闊な先入観」から出発して, 国際交流の為の往復書簡に使用する言語に 「すれ違い」を起こした事であるが，少なくとも私自身にとっては，思いがけなく中国語の超短期独学 
の機会が与えられた事になり，有害ではなくむしろ有益な面が多かった。実力の付く学習には到らなか ったが，これを機会に中国語の辞書を時々繙く楽しさを会得した事は大きな収穫であった。

先年当社の社員が訪中した際に彼と出会い，私に宜しくとの伝言を依頼されたといらが，もし今後面 会あるいは再文通の機会が生じた場合には，この一件の発端を確かめ，お互いの「迂闊な先入観」の及 ぼした影響について，益する面が多かったのではないかと，意見の交換をしたいと思っている。

私が中国語を使用できる様になるまでは，彼との文通は安心して日本語が使用できる事が判ったの で，今はストレスが全く解消されている。 